\title{
マクロ系の摩擦一紙，岩石から地震へ一
}

\author{
松川宏 \\ 青山学院大学理工学部 凿 229-8558 神奈川県相模原市淵野辺 5-10-1 \\ (2009 年 6 月 11 日受理)
}

\section{Friction of Macroscopic Systems-From Paper and Rock to Earthquake-}

\author{
Hiroshi Matsukawa
}

Department of Physics and Mathematics, Aoyama Gakuin University 5-10-1 Fuchinobe, Sagamihara, Kanagawa 229-8558

(Received June 11, 2009)

\begin{abstract}
The frictional phenomena appear in various systems. Their scales spread to extraordinary wide range. The frictional systems of large scale extend to landslide, glacier and earthquake, while those of small scale reach to sub-nanometer. There are universal behaviors in friction which are independent from the scale of the system. Typical examples are the maximum static frictional force, which is the threshold strength of the external force to cause the translational motion, and the kinetic frictional force, which results from energy dissipation accompanied by the caused motion. Besides these, stick-slip phenomena, memory effect of static frictional force, velocity dependence of kinetic frictional force and so on appear in various systems with wide range of scale. There are common mechanisms in these universal phenomena. Here we review frictional phenomena of various systems from a unified point of view.
\end{abstract}

KEYWORDS : friction, stick-slip, Amontons-Coulomb's law, adhesion theory, earthquake

\section{1. アモントン-クーロンの法則}

Fig. 1 に示すような二つの固体の間の滑り摩擦を考え よう。このようなマクロな系の摩擦については, 次のア モントンークーロンの法則が広く成り立つことが知られ ている ${ }^{1 \sim 4)}$ 。

1）摩擦は見かけの接触面積に依らない。

2）摩擦力は荷重に比例する。

3）動摩擦力は最大静摩擦力より小さく, 速度に依ら ない。

摩擦力を荷重で割った量を摩擦係数というが，これが 見かけの接触面積にも荷重にもよらないことになる。こ の法則のうち，1，2）はすでにレオナルド・ダ・ヴィン チが発見していたものである。彼の発見は一度, 歴史の 中に埋もれてしまい, その後, 産業革命の時代にアモン トン, クーロンによって再発見された。そのため, 上記 の法則はアモントンークーロンの法則と呼ばれる。

E-mail : matsu@phys.aoyama.ac.jp
この法則の成り立つ機構については今日, 次の凝着説 が広く信じられている ${ }^{1 \sim 4)}$ 。通常の固体表面はマイクロ スケールで見れば，凸凹がある。そのような固体を接触 させると，原子間力，分子間力により凝着するのは，一 部の凸と凸同士である。凸をアスペリティ, その凝着し ている部分を真実接触点, その総面積を真実接触面積と 呼ぶ。見かけの接触面積に比べ真実接触面積は小さく (通常, $10^{-2}$ 以下のオーダー), そこでの圧力は極めて 高くなり，一定の塑性流動圧力 $p_{\mathrm{p}}$ に達していると考え る。真実接触点での圧力が一定なのであるから, 荷重 $L$ を支えるためには真実接触面積 $A_{\mathrm{r}}$ が増えるしかない。 こうして $A_{\mathrm{r}}=L / p_{\mathrm{p}}$ となる。この真実接触点では原子間 力, 分子間力による凝着が起こっている。剪断力を加え て一方の物体を動かすには, その凝着を切らねばならな い。そのために必要な力が最大静摩擦力である。したが って, 最大静摩擦力 $F_{\text {max }}$ は凝着を切るのに必要な単位 面積あたりの力である剪断強さ $\tau_{\mathrm{s}}$ を使って, $F_{\max }=$ $\tau_{\mathrm{s}} L / p_{\mathrm{p}}$ と表され, 摩擦係数 $\mu$ は $\mu=\tau_{\mathrm{s}} / p_{\mathrm{p}}$ となり, 見か けの接触面積にも荷重にも依らないので, アモントン- 


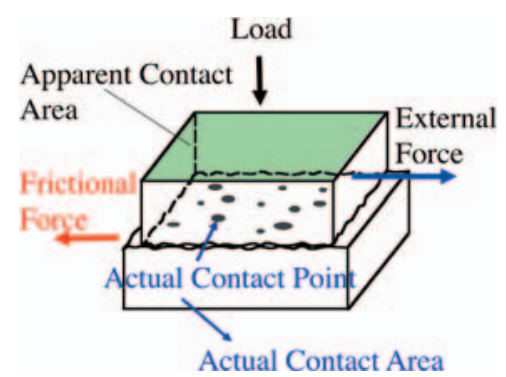

Fig. 1. (color online). Sliding friction and actual contact points.

クーロンの法則の 1，2）が説明された。これが摩擦の 凝着説である。この説の要点は真実接触面積が荷重に比 例することである。これは今日, 幾つかの方法で確かめ られている。しかし, 摩擦発生の機構については他の説 も提案されており，まだ解決済みの問題とは言えない段 階であろう ${ }^{5)}$ 。3）の動摩擦の振る舞いについては次節 で論じる。

\section{2. 紙, 岩石の摩擦}

さて，我々は日常生活でも引き戸の開閉などで，一定 速度の滑り運動が不安定になり，固着と滑りを繰り返す スティック・スリップ運動が起こる場合があるのを知っ ている。ではどのような条件下でそのような運動が起こ るのだろうか, アモントンークーロンの法則はどこまで 成り立つのであろうか? このような問題意識での実験 が紙を舞台として行われた ${ }^{6)}$ 。用いるのは市販の厚紙 で，台に厚紙を貼り，その上に重りを載せた厚紙をお き，それを後ろから一定速度で駆動されるバネで押して やる。

Fig. 2 はこの系で観測された運動の様子である。縦軸 は上の厚紙を駆動するバネのたわみであり，横軸は時間 である。重りが重いとある時間の間，上の厚紙は静止し 続け，その間，バネのたわみは増加し続ける。そしてバ ネの力が最大静摩擦力に達したときに厚紙は滑り, バネ の力が緩和し, 再び厚紙は静止する。このように, 静 止ースティックーと滑りースリップーを繰り返す，スティッ ク・スリップ運動が現れている。そして，重りを軽くす るとその振幅が小さくなり, ある臨界值より軽いと一定 速度の滑り運動が現れる。

実は，このスティック・スリップ運動が先に紹介した アモントンークーロンの法則の 3）の動摩擦力の振る舞 いの原因であると考えられている ${ }^{2,3)}$ 。3) は一定速度で の運動の際の動摩擦力の振る舞いである。しかし，その 定常的な運動は重心の運動についてである。一般に重心 が並進運動をするとき，Fig. 3 に示すように個々の真実

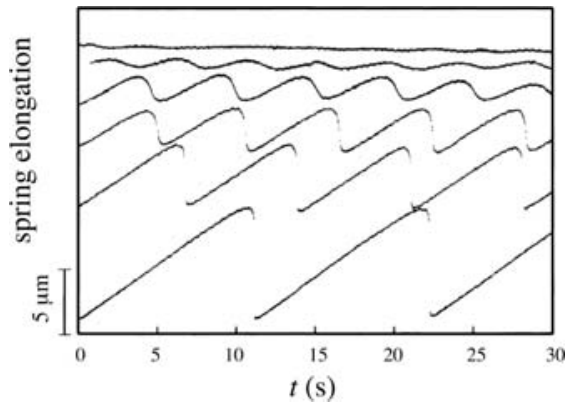

Fig. 2. Stick-slip motion of Bristol board. ${ }^{6}$ Upper (lower) curves represent the time evolution of driving-spring elongation with lighter (heavier) weight.

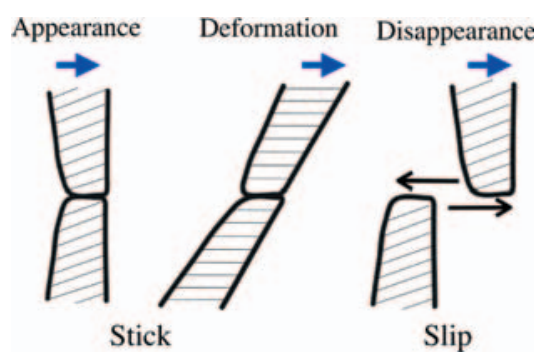

Fig. 3. (color online). Appearance, deformation and disappearance of an actual contact point during sliding motion.

接触点は生まれ, 変形し, 消滅する, というサイクルを 繰り返す。このとき, 重心が一定速度で動いていても, 個々の真実接触点はスティック・スリップ運動をしてい る。そして, スリップの高速運動の時に, 大きなエネル ギー散逸を起こし，これが動摩擦への主要な寄与と考え られる。このスリップの速度は重心の滑り速度とは無関 係である。そのため, 動摩擦力は滑り速度に依らなくな るのである。この局所的なスティック・スリップ運動が 速度に依存しない動摩擦を生じることは, 微視的なモデ ルでは確かめられている ${ }^{3,7)} 。$

しかし, 動摩擦力が滑り速度に依らないというのはあ くまで限られた速度領域でみた場合，あるいは後述する 有限温度の効果が無視できる系での話であり, 一般には 第 0 近似的な振る舞いである。Fig. 4 の黒丸は同じく厚 紙の, 一定速度での滑り運動の領域での動摩擦係数の速 度依存性を示している ${ }^{6)}$ 。この範囲で見ると動摩擦係数 は明らかに速度依存性があり, 対数関数的に減少してい る。アモントンークーロンの法則の 3）はこのような広 い速度範囲でみると成り立たない。一方，この図の白丸 は静摩擦係数の待機時間 $t_{\text {stick, }}$, すおち滑る前の静止時 間，依存性を示しており，ある長さ $D_{\mathrm{c}}$ を $t_{\text {stick }}$ で割った 量に対してプロットしてある。この系の最大静摩擦力は 


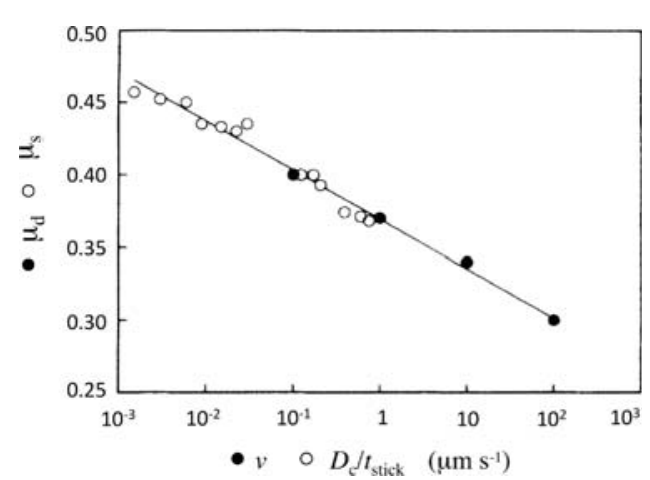

Fig. 4. The velocity, $v$, dependence of the kinetic frictional coefficient $\mu_{\mathrm{k}}$ (black circle) and the waiting time, $t_{\text {stick}}$, dependence of the static frictional coefficient $\mu_{\mathrm{s}}$ (open circle). From ref. 6).
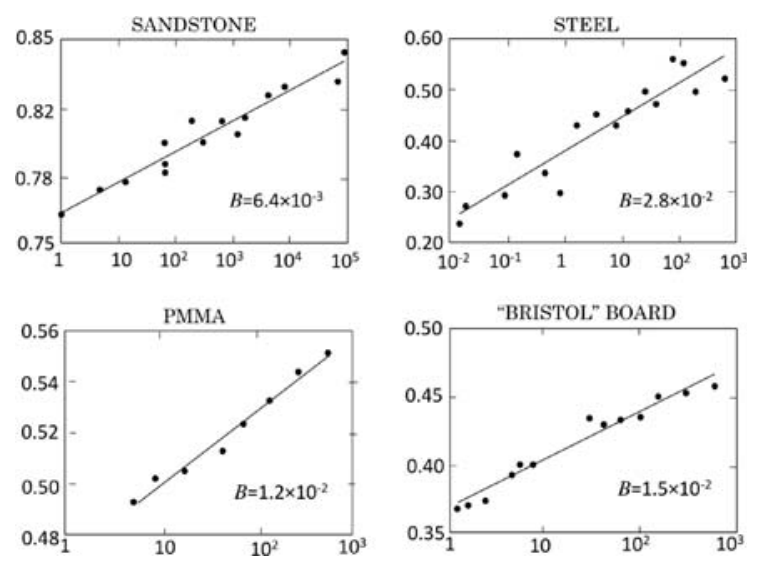

Fig. 5. The waiting time $t_{\text {wait }}$ dependence of the static frictional coefficients $\mu_{\mathrm{s}}$ of sandstone, steel, PMMA and Bristol board. ${ }^{8)}$ The vertical and horizontal axes are $\mu_{\mathrm{s}}$ and $t_{\text {stick }}(\mathrm{s})$, respectively. The parameter $B$ comes from the logarithmic fit $\mu_{\mathrm{s}}\left(t_{\text {wait }}\right)=\mu_{0}^{\prime}+B \ln$ $\left(t_{\text {wait }}\right)$. See eqs. $(2,4)$. From ref. 8).

待機時間に依存し, 滑る前の静止時間が長いほど大きく なる，のである。そして黒丸と白丸は同じ直線にのる， つまり最大静摩擦力の待機時間依存性は動摩擦力の速度 依存性でスケールされる。

このような静摩擦力の対数関数的待機時間依存は決し てこの系に限られる特殊な現象ではない。Fig. 5 に砂 岩, 鋼, PMMA (高分子材料), 厚紙の静摩擦係数の待 機時間依存性を示す ${ }^{3,8)}$ 。このように対数関数的待機時 間依存性は多くの物質で観測されており, 一般的性質で あると考えられる。この待機時間依存性は, 最大静摩擦 力が止まっている時間を覚えているという記憶効果であ る。

では, 動摩擦力の速度依存性はどうなのであろうか? これについても過渡現象まで含めて研究されている。

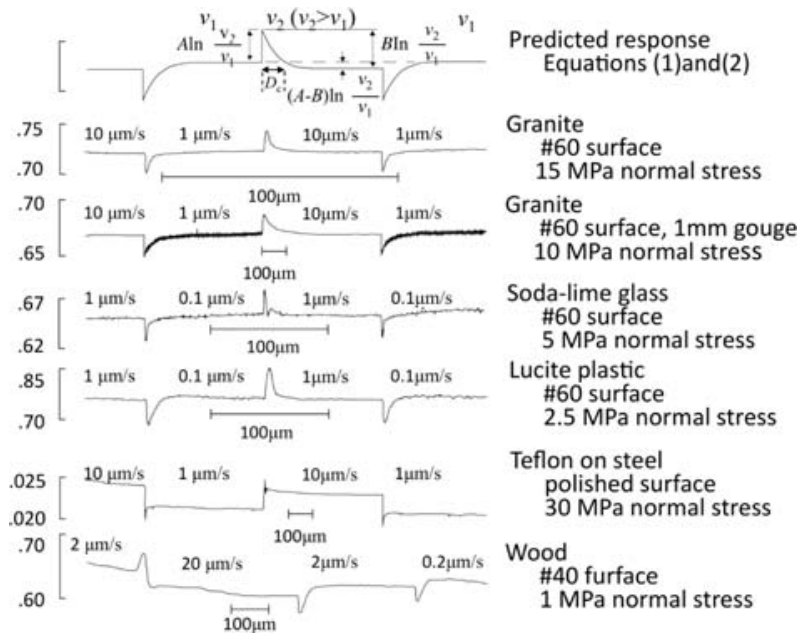

Fig. 6. The response of the kinetic frictional coefficients against the change of the driving velocity of granite, soda-lime glass, lucite plastic, teflon on steel and wood. From ref. 9).

Fig. 6 にさまざまな物質の摩擦係数の駆動速度の変化に 対する応答を示す $2,3,9,10)$ 。一般に駆動速度を増加（減 少）させたとき, 摩擦係数は瞬時に増加（減少）し, そ の後, ゆっくりと, その速度での定常的な值に緩和して いく。このように速度変化に対しては瞬時に対応する過 程-直接過程-とゆっくりと対応する過程-間接過程-が存 在する。これについては後に詳述する。

このように一般的に, 動摩擦力は駆動速度に, 最大静 摩擦力は待機時間に依存する。しかし, その依存性が弱 く, 通常の実験は限られた速度領域, 限られた待機時間 範囲で行われるため, 顕著には表れず，アモントンーク ーロンの法則が成立して見えると考えられる。

\section{3. 摩擦の構成則}

では，摩擦力の待機時間依存性と速度依存性をもたら す機構は何であろうか？ Fig. 7 にアクリルガラスの真 実接触点の待機時間依存性を示す $2,3,9)$ 。真実接触点を観 測するのは容易ではないが, ここではアクリルガラスと いう透明な試料を用いて, 透過光により真実接触点を観 測している。2 枚のアクリルガラスをセットしてからの 待機時間とともに, 真実接触面積が増加していることが わかる。その増加の時間依存性が対数関数的であること も実験により確かめられている。この真実接触面積の増 加が最大静摩擦力の増加をもたらすことは, 凝着説の説 明からわかるだろう。一方, 動いているときには, 各真 実接触点は先に述べたように, 生成, 変形, 消滅を繰り 返しており, 真実接触点の平均の “待機時間” は重心の 滑り速度に反比例するだろう。すると, この真実接触面 


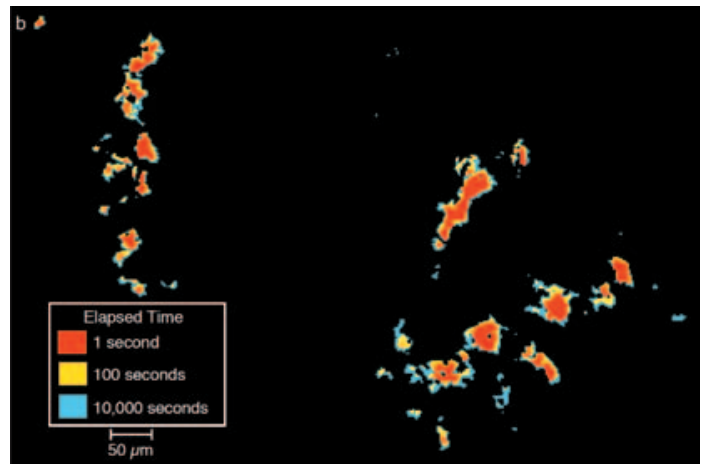

Fig. 7. (color online). The waiting time dependence of actual contact points between surfaces of acrylic plastic. ${ }^{9)}$ The red, yellow and blue area represent actual contact area for $\tau_{\text {stick }}=1,100,10000 \mathrm{~s}$, respectively. From ref. 9).

積の待機時間依存性は対数関数的に速度とともに減少す る動摩擦力を生じることになる。これは, Fig. 4 で見た 厚紙の動摩擦力の振る舞いを説明する。しかし, この機 構だけでは, Fig. 6 の速度変化に応答する二つの過程直接過程と間接過程一の存在が説明できない。

このような摩擦の待機時間依存性，速度依存性を説明 する摩擦の構成則と呼ばれる現象論的モデルが提案され

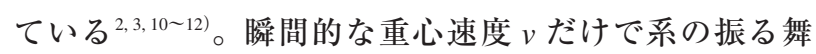
いを記述できないことは明かである。そこで，もう一 つ, 系の状態を表す変数 $\theta$-状態変数と呼ばれる一を導入 する。そして, 摩擦係数 $\mu$ は次のように表されるとす る。

$$
\mu=\mu_{0}+A \ln \left[1+\frac{v}{v_{0}}\right]+B \ln \left[1+\frac{\theta}{\theta_{0}}\right]
$$

ここで, $A, B, \quad v_{0}, \theta_{0}$ は定数である。実際に問題と なる速度 $v$ および状態変数 $\theta$ は（ $v=0$ の場合を除き） $v_{0}, \theta_{0}$ に比べ十分大きく，そこでは上の式は，

$$
\mu=\mu_{0}+A \ln \left[\frac{V}{V_{0}}\right]+B \ln \left[\frac{\theta}{\theta_{0}}\right]
$$

となる。（1，2）式第 2 項を直接項, 第 3 項を間接項と いう。状態変数 $\theta$ は次の方程式に従って時間発展する。

$$
\frac{d \theta(t)}{d t}=1-\frac{\theta v}{D_{\mathrm{c}}}
$$

ここで $D_{\mathrm{c}}$ は長さの次元を持つ定数である。この時間発 展方程式の解は容易に求まり, 重心の座標 $x_{\mathrm{G}}(t)$ を用い て次のように表される。

$$
\theta(t)=\int_{0}^{t} \exp \left\{-\frac{x_{\mathrm{G}}(t)-x_{\mathrm{G}}\left(t^{\prime}\right)}{D_{\mathrm{c}}}\right\} d t^{\prime}
$$

先ず静止状態を考えてみよう。このとき（4）より $\theta=t$ となりこれと $v=0$ を（1）に代入し, $\mu=$ const. + $B \ln t$ を得る。これより静摩擦係数は待機時間に対数関 数的に依存することになる。一方, 定常滑りの状態で

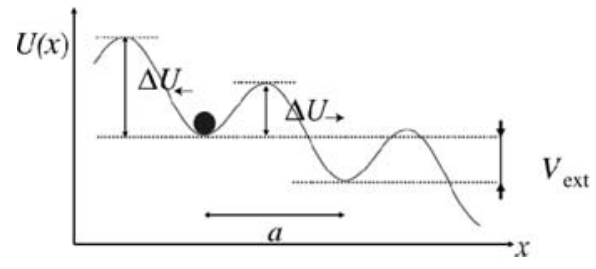

Fig. 8. An point particle in a tilted periodic potential.

は, 状態変数は時間変化しないので, $(3)$ より $\theta=D_{\mathrm{c}} / v$ となり,これを（1）に代入して

$$
\mu=\text { const. }+(A-B) \ln v
$$

と速度に対数関数的に依存する動摩擦係数を得る。一 方，速度変化に対する応答では，（3，4）式を通じての $\theta$ の時間発展には有限の時間が必要なため, 間接項の応 答には遅れが生じる。これに対して, 直接項は瞬時に応 答するので Fig. 6 の振る舞いを説明できる。Fig. 6 の一 番上の線は（1４）式によって表される振る舞いを描い たものである。こうして, 摩擦の構成則という現象論に より摩擦力の待機時間依存性と速度依存性が再現でき た。

では, この摩擦の構成則の背後にある微視的機構は何 であろうか? 先ず直接過程から考えてみよう。これは真 実接触点を構成するアスペリティのクリープ運動による と考えられている ${ }^{2,3,6)}$ 。現実の物質では摩擦面のアスペ リティの位置, 形状はランダムであるが, 一つのアスペ リティに注目しその 1 次元的運動を考え, これが接する もう一方の面から受ける相互作用を, 簡単のため位置に 関しての周期ポテンシャルで表そう。ここに外力が加わ ると,このアスペリティは Fig. 8 のような傾いた周期ポ テンシャル中の質点としてモデル化することができる。 傾きは駆動力により生じる。温度は十分低温で, アスペ リティはほとんどの時間, ポテンシャルの谷底にいる が, 時々熱摇らぎにより, 左右のポテンシャルバリアー を越え運動するものとする。このとき，アスペリティの 座標 $x$ の時間発展は次のように表すことができる。

$$
\frac{d x}{d t}=a \omega_{0}\left\{\exp \left[\frac{-\Delta U_{\rightarrow}}{k_{\mathrm{B}} T}\right]-\exp \left[\frac{-\Delta U_{\leftarrow}}{k_{\mathrm{B}} T}\right]\right\}
$$

ここで $a$ はポテンシャルの周期, $\omega_{0}$ はアテンプト周波 数, $k_{\mathrm{B}}$ はボルッマン定数, $T$ は温度である。十分低温を 考えることにし左のより高いバリアーを越える確率を無 視する。さらにポテンシャルバリアー $\Delta U$ が外力 $F_{\mathrm{ext}}$ の ない場合のバリアーの高さ $U_{0}$ を用いて, $U_{0}-F_{\mathrm{ext}} \mathrm{a} / 2$ と 表されること, 定常運動では外力と摩擦力は等しいこと を使うと,

$$
F_{\text {fric }}(v)=F_{\text {fric }}^{0}+A^{\prime} \ln v
$$

を得る。これが直接項である。このように速度とともに 
対数関数的に増加する摩擦力は摩擦力顕微鏡を用いた実 験でも観測されている ${ }^{13)}$ 。摩擦力顕微鏡の針を一つのア スペリティと考えれば当然の結果であろう。

一方, 一定の荷重下では各真実接触点に垂直応力が加 わり，これにより真実接触点は塑性変形する ${ }^{2,3)}$ 。この 塑性変形はアスペリティ内の転位のクリープ運動による ものである。このときも上と同じような熱活性化型の運 動が生じて, その結果, 先に見たように真実接触面積が 待機時間とともに増加する。この増加の様子は対数関数 的であることを簡単なモデルでは示すことができる。さ らに待機時間を運動状態にまで一般化し状態変数を導く ことも可能であり，間接項を得ることができる。このよ うにして, ある程度微視的なモデルから出発して摩擦の 構成則を導くことができる。

これらのクリープ運動はバリアを乗り越える熱活性化 型過程によるものであり, 有限温度の効果である。バリ アの高さに比べて十分低温では, これらの効果は無視で きる。そこでは, 動摩擦力の速度依存性や最大静摩擦力 の待機時間依存性もなくなると期待される。

\section{4. スティック・スリップ運動と地震}

前節までで, 摩擦力には待機時間と速度への依存性が あることを紹介し，それを記述する摩擦の構成則という 現象論, さらにそれを導く微視的機構を議論してきた。 ここで, 定常状態での摩擦の速度依存性の式（5）をも う一度, みてみよう。 $\ln v$ の前の係数 $(A-B)$ が正な ら, 摩擦力は速度とともに増加し, 負なら減少する。後 者の場合, 一定速度での運動が不安定となる。摇らぎに より速度が増加すれば摩擦力が減少し, さらに速度が増 加するからである。一定速度の運動が不安定化して起こ るのは先に述べたスティック・スリップ運動であ る $^{2,3,5,10,11)}$ 。

さて, スティック・スリップ運動も至る所に現れる現 象であるが, そのうち最もスケールの大きな現象の一つ が地震であろう ${ }^{2,3,5,10,11)}$ 。地震には幾つかの機構がある が, 多くの巨大地震が属するプレート間地震の機構を

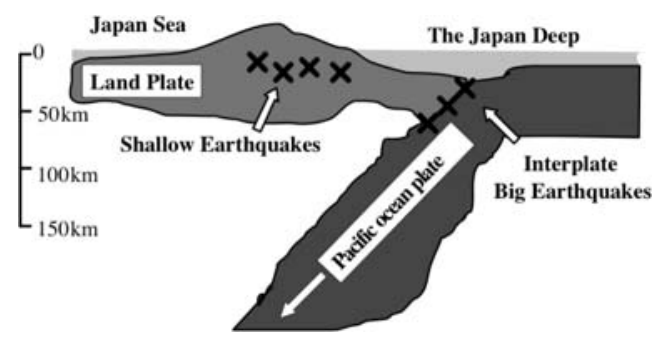

Fig. 9. Plates around Japan and the interplate earthquake. The shape of the plates is simplified.
Fig. 9 に示す。太平洋から海洋プレートが進んできて, 大陸プレートにぶつかると, 海洋プレートの方が重いの で下に潜り込む。その際，大陸プレートも一緒に引きず り込み, 大陸プレートは歪む。これはスティック状態で ある。その歪みを戻そうとする復元力がプレート間の最 大静摩擦力に達したところで大陸プレートはスリップす る。これがプレート間地震である。このように地震はス ティック・スリップ運動の一種と考えられるわけである が, 先に述べた厚紙の摩擦などに現れるスティック・ス リップ運動とは大きな違いがある。それは, 後者は周期 的であるが, 地震は非周期的であり, その頻度分布がグ ーテンベルグ・リヒター則という幕乗則に従う, つまり 2 倍強い地震は $1 / 2^{\alpha}$ の頻度でしか起こらない, という 点である ${ }^{2,3,10,11)}$ 。このグーテンベルグ・リヒター則の成 立範囲, 成立機構などに関しても観測, 実験, 計算機シ ミュレーションなどによる多くの研究があり摩擦の問題 としても極めて興味深いものがあるが，ここでは紙幅の 関係で割愛する ${ }^{3,14,15)}$ 。

スティック・スリップ運動が起こる条件を再び議論す る $^{2,3,10,11)}$ 。先に摩擦力が速度とともに減少するとき, ス ティック・スリップ運動が起こると述べた。それは摩擦 力が瞬間的な速度だけで決まる場合である。一般にはそ うはならず, 摩擦の構成則でもわかるように, 摩擦力の 速度変化に対する応答には遅れがある。そのときは, ス ティック・スリップ運動の起こる条件は駆動系の有効バ 交定数にも依存する。しかし, 摩擦力が速度とともに減 少すること, 摩擦力の速度依存性の式（5）でいえば $(A-B)$ が負になることが必要条件であることに変わり はない。地震の多発带として有名なカリフォルニアのサ ン・アンドレアス断層でのプレートを構成する主要岩石

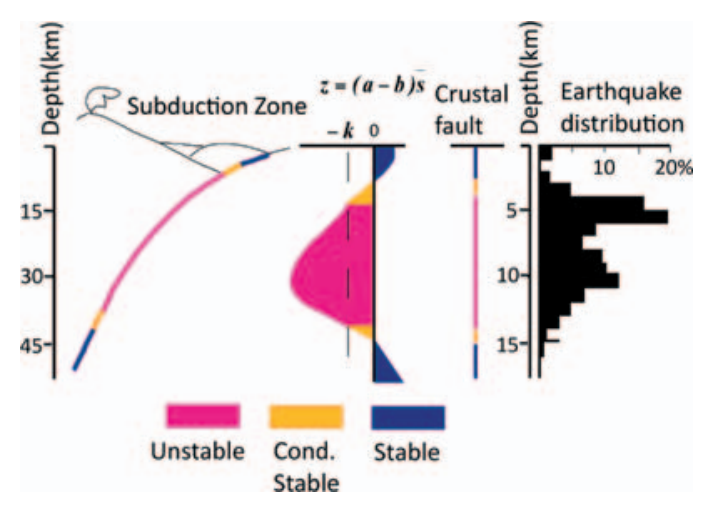

Fig. 10. (color online). The frictional parameter $(A-B)$ and the stability as a function of the depth of the crustal faults and subduction zone and the earthquake distribution. ${ }^{11)}$ The stability of the yellow zone depends on the effective spring constant of the fault. From ref. 11). 
である花崗岩について, この $(A-B)$ の温度, 圧力依 存性の測定が行われた。地中では深度とともに温度，圧 力が増加する。この実験を基にサン・アンドレアス断層 における $(A-B)$ の深度依存性を評価したのが，Fig. 10 の左のパネルである。“Stable” の領域が $(A-B)$ が正 で定常運動が安定であり, 媣度 3 15 km の領域では負 になっている。一方，右のパネルはこの断層の地震の震 源の深度分布である。 $(A-B)$ が負の領域に震源が集中 していることがわかる。このように地震の発生はその断 層を構成する岩石の摩擦のパラメーターで決まっている のである。

\section{文献}

1) 摩擦についての一般的な解説書として, 曾田範宗: “摩擦のはなし” (岩波新書, 1971) がある。身近な摩 擦の実験や人間生活と摩擦の関係, 摩擦の研究, 理解 の歴史にまでふれた名著である。

2) 物理的視点から幅広い題材を扱った教科書として B.N.J. Persson: "Sliding Friction-Physical Principles and Applications-", 2nd edition (Springer, Berlin, 2000).

3) 松川 宏: “滑りと摩擦の科学”, 非線形科学シリー ズ : 液晶のパターンダイナミクス, 滑りと摩擦の科
学 (培風館, 2009).

4）最近の会議録としでProceedings of International Conference on Science of Friction, Irago 2007”, ed. by K. Miura and H. Matsukawa, Journal of Physics : Conference Series, 89 (2007).

5) G. He, M.H. Musser and M.O. Robbins : Science 284, 1650 (1999).

6) F. Heslot, T. Baumberger, B. Perrin, B. Caroli and C. Caroli : Phys. Rev. E49, 4973 (1994).

7) H. Matsukawa and H. Fukuyama : Phys. Rev. B49, 17286 (1994).

8) T. Baumberger : Solid State Commun. 102, 175 (1997).

9) J.H. Dieterich and B.D. Kilgore: Pure and Appl. Geophys. 143, 283 (1994).

10) C.H. Scholz: "The Mechanics of Earthquake and Faulting” (Cambridge Univ. Press, 1990) (邦訳 “地震と断層 の力学”, 柳谷俊訳 (古今書院, 1993)).

11) C.H. Scholz : Nature 391, 37 (1998).

12) A.L. Ruina : J. Geophys. Res. 88, 10359 (1983).

13) R. Bennewitz, E. Gnecco, T. Gyalog and E. Meyer : Tribology Lett. 10, 51 (2001).

14) J.N. Carlson and J.S. Langer : Phys. Rev. Lett. 62, 2632 (1989).

15) T. Saitou and H. Matsukawa : Journal of Physics: Conference Series 89, 012016 (2007). 